ERR A T UM

Gül Özçelik • Tuğçin Bora Polat • Seniha Aktaş •

Feyzullah Çetinkaya

\title{
Resistive index in febrile urinary tract infections: predictive value of renal outcome
}

Published online: 10 March 2004

(C) IPNA 2004

\section{Pediatr Nephrol (2004) 19:148-152}

It has come to our attention that the name of the fourth author of this article was misspelled as Fetinkaya. The correct spelling is Çetinkaya. (It has already been corrected above in the author line).

The editors apologize for this error.

The online version of the original article can be found at http://dx.doi.org/10.1007/s00467-003-1305-z

G. Özçelik · T. B. Polat · F. Çetinkaya

Department of Pediatrics,

Şişli Etfal Hospital, Istanbul, Turkey

S. Aktaş

Department of Radiology,

Şişli Etfal Hospital, Istanbul, Turkey

G. Özçelik (ه)

PK.198, 80622, 1 Levent, Istanbul, Turkey

e-mail: ozcelik@istanbul.edu.tr

Tel.: +90-212-2874828

Fax: +90-212-2306910 